\title{
CONEXÃO DA CARREIRA: \\ $\Delta$ uma análise comparativa de preferências e insulamento burocrático
}

\section{Ben Ross Schneider \\ Traduçāos Istvan Va|da}

cada ano, muitos dos mais brilhantes recém-formados das melhores universidades dos Estados Unidos, da f́cole Nationale d'Administration (ENA) na França, da Universidade de Tóquio, da Universidad Nacional Autónoma de México (UNAM), e da Universidade Federal do Rio de Janeiro têm ido trabalhar para os seus respectivos governos. Mas quando eles assinam os seus contratos de trabalho, têm expectativas diferentes sobre o que significa ser um servidor público e como a sua carreira futura prova. velmente se desenvolverá. Essas diferentes expectativas c trajetórias de carreira devem ter grande importância com relaçāo à distância e a autonomia que os servidores nesses cinco países têm de grupos de fora do Estado, principalmente das grandes empresas.

A análise a seguir concentra-se no isolamento ou na autonomia burocráticas, definido como a oportunidade dos servidores de

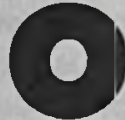

trabalbo ressalta a relação entre os futuros servidores governamentais com o se. tor privado, enfocando as interfaces construidas, por um lado, pelas perspectivas funcionats nas carreiras do setor público $e$, por outro, pelas influências do poder económico exercidas através do empresariado. Nesse sentido, dados sobre as experiências norte-americana, francesa, japonesa, mexicana e brasiletra são apresentados.

seguir preferências e de formular politicas de forma independente. Quais as prováveis origens das preferências dos servidores, e que incentivos têm para atender os interesses dos atores sociais na formulação de políticas? $\mathrm{O}$ meu angumento na forma mais simples é que, quanto menos as empresas afetarem as carreiras dos burocratas, maior será a oportunidade dos burocratas de desenvolverem e seguirem preferências de centralização estatal e, portanto, maior será o potencial para a autonomia burocrática. Entretanto, em que 
medida os burocratas realmente aproveitam esse potencial, está além do escopo deste artigo. $O$ ponto de partida é que os burocratas estão interessados, em primeiro lugar, em suas carreiras, c esse interesse cen tral, por sua vez, influencia as preferências com respeito a políticas $\mathrm{c}$ a tomada de decisāo. Como escreveu um sincero burocrata de elite : "os servidores indicados pelo presidente tềm em mente, como primeiríssima prioridade, o seu proprio futuro", o que, dados os padrōes de carreira nos Estados Unidos, gera uma "rastejante falta de firmeza de caráter no Poder Executivo.'

O foco principal da análise é sobre o setor empresarial e o isolamento, por parte da burocracia, deste setor. Essa relação entre o empresariado e a burocracia estatal sempre foi problemática, na prática e na tcoria (especialmente com respeito ao desenvolvimento liderado pelo Estado), uma vez que os capital istas têm todos os incentivos para utilizar seu poder econômico para tentar influenciar o Estado. A minha abordagem complementa as análises comparativas anteriores das relaçōes entre burocratas e políticos e remedia a relativa negligência com que foi tratado o relacionamento cntre burocratas e empresariado. ${ }^{2} \mathrm{O}$ argumen to e o método, entretanto, poderiam ser facilmente empregados em uma análise mais completa do isolamento burocrático que cobrisse todos os grupos políticos e sociais de fora da burocracia que influen ciam as carreiras.

A maior parte da teorização sobre preferências burocráticas é dedutiva e trabalha com versões mais ou menos sofisticadas da lei de Miles, segundo a qual a posição dos servidores a respeito de uma questāo em particular depende de

\footnotetext{
1 - Paul Craig Roberts, Secretário Adjunto do Tesouro, 1981-82, escrevendo no New York Times, $l^{\circ}$ de dezembro de 1988.

2 - ABERBACH, Joel D., PUTNAM, Robert D., ROCKMAN, Bert A. Bureaucrats and Politicians in Western Democracies. Cambridge, Mass.: Harvard University Press, 1981; DOGAN, Mattei, eds. The Mandarins of Western Europe. Nova Iorque: Sage/ Halsted, 1975; SUl.EIMAN, Ezra N., ed. Bureaucrats and Policy Maktng. New York: Holmes and Meier, 198.4; ARMSTRONG, John A. The European Administrative Elite. Princeton: Princeton University Press, 1973. Para estudos de caso de relaçōes entre burocratas e politicos nos paises estudados aqui, veja: ARNOLD, R. Douglas. Congress and the Bureaucracy. New Haven: Yale University Press, 1979; PARK, Yung H. Bureaucrats and Ministers in Contemporary Japanese Government. Berkeley: University of California Institute of East Asian Studies, 1986; MURAMATSU, Michio. KRAUSS, Ellis S. "Bureaucrats and Politicians in Policymaking: The Case of Japan". American Political Science Review, 78, março de 1984, p. 126-146; SUL.ELMAN, Ezra N. Elites in French Society. Princeton: Princeton University Press, 1978; SMITH, Peter H. Labyrinths of Power: Political Recruitment in Twenticth Century Mexico. Princeton: Princeron University Press, 1979; e DALAND, Robert T. Exploring Brazilian Bureaucracy: Peformance and Pathology. Washington D.C.: University Press of America, 1981.
} 
onde cles estāo sen tados. ${ }^{3} \Lambda$ minha abordagem alternativa para as carreiras tem uma visão mais realista, de prazo mais longo: a posição dos servidores depende de onde eles estavam e para onde estão indo. Do ponto de vista da carreira, a lei de Miles vale apenas se a estrutura temporal for especificada: a posiçāo dos servidores depende de onde eles estão sentados somente se estāo sentados ali há bastante tempo. Esse tipo de visão sedentária é adequada para boa parte do serviço público norteamericano, mas não, como discutido adiante, para as burocracias de outros países.

As seçōes a seguir examinam cinco dimensóes da carreira dos servidores públicos.

- Qual é a base social de recrutamento da elite burocrática?

Quão estreito é o funil educacional, e o curso universitário estimula o surgimento de uma elite estatal?
As carreiras estāo vinculadas ao Fstado ou a orgãos individuais?

Como os servidores progridem na carreira?

Para onde vão os servidores quando deixam o Estado?

São hipoteticamente possíveis duas situaçōes completamente opostas. Em uma trajetória isolada, de centralizaçāo estatal, os burocratas vêm das classes profissionais assalariadas, matriculam-se em uma universidade competitiva, de onde todos os formados ingressam no serviço público, entram na burocracia (e mais tarde são promovidos) mediante exames ou avaliações impessoais, circulam amplamente por vários órgãos e aposentam-se da burocracia no final de sua vida profissional ativa. Em uma trajetória oposta, social (ou de elite do poder) os burocratas em potencial vêm do topo das classes capitalistas, estudam em universidades que como primeira prioridade treinam estudantes para ingressar no mundo empre-

3

- MH.ES, JR., Rufus E. "The Origin and Meaning of Miles' Law". Public Administration Review, 38, setembro-outubro de 1978. Isso é verdade a respeito da abordagem de escolha do público que se concentra nos orçamentos e nos modelos de política burocrática. Veja, respectivamente. NISKANEN JR., William A. Bureaucracy and Representative Government. Chicago: Adine, 1971, p. 36.42; e AILLISON, Graham. "Conceptual Models and the Cuban Missile Crisis". American Political Science Review, 63, setembro de 1969 , p. 689-718. Outros exemplos incluem: NORDLINGER, Eric A On the Autonomy of the Democratic State. Cambridge, Mass.: Harvard Universiry Press, 1981, p. 31-33, e DUVALL, Raymond D., FREENAN, John R. "The Techno-Bureaucratic Elite and the Entreprencurial State in Dependent Industrialization". American Political Science Review, 77, sctembro de 1983, p. 569587. 
sarial e dos negócios, ingressam no serviço público (muitas vezes por pouco tempo), são promovidos por indicação pessoal, trabalham para um único órgão e aposentam-se ainda jovens, passando a ocupar cargos muito bem remunerados na in iciativa privada. A minha hipótese é que os burocratas de elite que seguem essas trajetórias ou trajetórias híbridas, passarão a ter preferências, relaçōes com capitalistas e níveis de autonomia diferentes.

Nenhum dos cinco países estudados se encaixa em qualquer um dos extremos, embora o Japão c a França tendam para o pólo de cen tralização estatal, enquanto os Estados Unidos, o México e o Brasil têm elementos de um modelo social mais permeável.
Esses cinco casos ilustram a ampla gama de variação entre países, o que contradiz as impressōes de convergência e uniformidade, e permite uma pausa aos teóricos antes deles criarcm tcorias universais de burocracia. Com a exceção dos Estados Unidos, a seleção dos casos permite a comparaçāo de quatro países de caráter desenvolvimentista que parecem semelhantes no que diz respeito ao tamanho e propósito de sua intervenção econômica, mas que possuem formas muito diferentes de autonomia burocrática. Análises comparativas de industrialização liderada pelo Estado geralmente destacam a autonomia ou o isolamen to burocrático como uma variâvel decisiva na explicação do rápido desenvolvimento econômico. ${ }^{4}$ Se

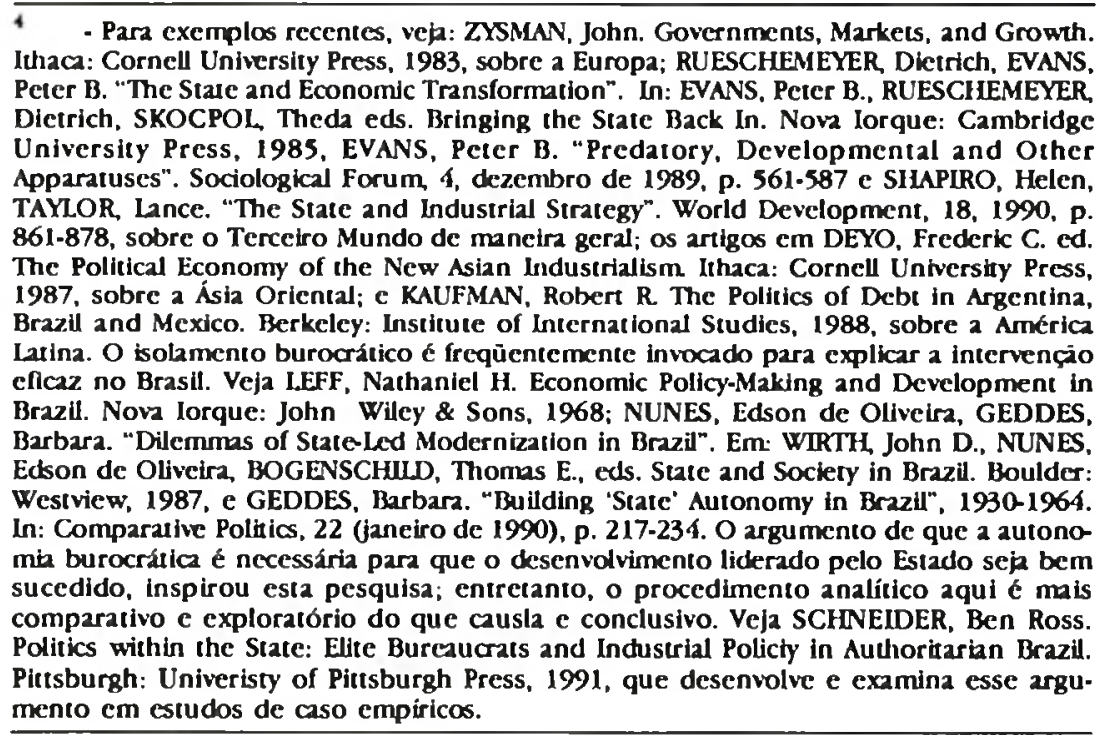


isso for verdade, a comparaçāo entre carreiras burocráticas é um fator primordial na determinação das fontes prováveis e da natureza variável do isolamento.

\section{A análise das carreiras burocráticas} é importante para vários outros debates téricos e normativos, mais amplos. Por exemplo, as teorias neo-marxistas têm como questāo central a autonomia e a orientação do Estado em uma sociedade capitalista. Tanto a teoria estruturalista como a instrumentalista do Estado capitalista poderia beneficiar-se de uma maior atenção às carreiras burocráticas para definir quando os burocratas podem ter incentivos para atender aos interesses de capitalistas individuais $\mathrm{e}$ quando eles podem ter a autonomia para equilibrar demandas concorrentes e favorecer os interesses de setores da economia como um todo.s
Os estudos que se concentram principalmente nas estruturas, organizações $\mathrm{e}$ instituições (como no novo institucionalismo) do Estado, argumentam que os procedimen tos e a organização do Estado determinam as opçóes que os burocratas têm. ${ }^{6}$ Esse ponto de vista tem mais sentido quando as instituiçôes são relativamente resistentes à mudanças. A viscosidade organizacional surge quando os servidores defendem o seu órgão (e seus procedimentos e prerrogativas), o que é mais provável que façam se as instituiçóes afetarem sua carreira. Caso contrário, o resultado poderá ser o tipo de falta de firmeza institucional e organizacional, à medida que os bu rocratas circulam indiferentemente pelos cargos. De forma análoga, surgem preferências visíveis pelo Estado ou pela instituição quando os servidores

5 - Para um ponto de vista contrário, veja POULANTZAS, Nicos. Classes in Contemporary Capitalism. Londres: Verso, 1978, p. 175-189. Veja CARNOY, Martin. The State and Political Theory. Princeton: Princeton University Press, 1984, para uma visão geral das teorias sobre o Estado capitalista. As teorias que trabalham com a abordagem da elite de poder tem se preocupado primordialmente com elementos de carreiras, assim como com origem social e interaçào. Infelizmente, seu trabalho empirico trata quase que exclusivamente dos Estados Unidos. Veja MULS, C. Wright. The Power Elite. Londres: Oxford University Press, 1956; DOMHOFF, G. William. The Higher Circles. Nova Iorque: Vintage, 1970; e DOMHOFF, G. William. The Powers That Be. Nova lorque: Vintage, 1978.

6 - Sobre o novo institucionalismo, veja MARCH, James G. OLSEN, Johan P. "The New Institutionalism". In: American Political Science Revicw, 78, setembro de 1984. p. 734-749; IKENBERRY, John G. "Conclusion: An Institutional Approach to American Foreign Economic Policy". In: International Organization, 42. Inverno de 1988, p. 222-229; HALL. Peter A. Governing the Economy. Nova Iorque: Oxford University Press, 1986, p. 231-234; THELEN, Kathleen, STEINMO, Sven. "Historical Institutionalism in Comparative Politics". In: STEINMO, Sven, THELEN, Kathleen, LONGSTRETH, Frank, eds. Structuring Politics. Cambridge: Cambridge University Press, 1992. Sobre perspectivas de centralizaçäo estatal, veja EVANS, RUESCHEMEYER. SKOCPOL, eds., op. cit. 
trabalham por anos a fio somente para o Estado ou para órgãos governamentais específicos.

As abordagens de centralização estatal, organizacional e institucional precisam acoplar as instituições a incen tivos (aqueles modelados por padróes de carreira na minha análise) e ser sensiveis com respeito à sua amplitude de variação transnacional. Colocando de outra forma, essas abordagens não podem, a priori, identificar quais das milhares de organizaçōes e procedimentos formais e informais do Estado sāo realmente importantes. A análise de carreira é um método eficaz de separar dessa multidão as instituições que têm maior probabilidade de distribuir poder e de moldar comportamento.

As teorias de escolha racional e pública que aplicam a teoria microeconômica para estudar a política da burocracia, geralmente in iciam com algumas suposições muito restritivas a respeito de interesses e preferências caracteristicas da disciplina-māe. Niskanen, por exemplo, desenvolveu uma teoria influente de comportamento de órgão público com base na suposição que os burocratas desejam prioritariamente maximizar os seus orçamentos. ${ }^{7}$ Tais suposições restritivas, e as teorias elegantes construídas sobre elas, podem ser aplicáveis a países onde vale a lei de Miles, mas nāo em outros lugares. $O$ problema surge novamente da dedução das preferências dos servidores a partir dos atributos de seus órgāos, sem levar cm conta como ocorre o desenvolvimento das preferências de forma informal e ao longo do tempo. O problema dessas teorias gerais pode também surgir de uma atenção excessiva ao caso dos Estados Unidos, em que a análise comparativa das burocracias identifica-se consistentemente como um caso extremo. Mais recentemente e de maneira geral, alguns teoristas de primeira lin ha têm buscado noçōes de preferências que são mais flexíveis, mais empíricamente ancoradas. ${ }^{8} \mathrm{~A}$ análise de carreiras deveria ser um elemento crucial nessa busca.

Em uma abordagem mais atual, as constantes controvérsias sobre

\footnotetext{
7

- NISKANEN, op. cil., p. 36-42.

- Veja BATES, Robert H. "Macropolitical Economy in the Field of Development", e RUKER, William H. "Political Science and Rational Choice", ambos em: ALT, James E., SHEPSLE, Kenneth, eds., Perspectives on Positive Political Economy. Cambridge: Cambridge University Press, 1990, especialmente p. 53.54 e 173.175; e NORTH, Douglass C. Institutions, Institutional Change and Economic Performance. Cambridge: Cambridge University Press, 1990, p. 18-22.
} 
a ética no governo, especialmente nos Estados Unidos e no Japão, freqũentemente giram em torno de questôes a respeito do tipo de cargos que os burocratas de alto nivel podem assumir antes e depois do serviço público. Quanto tempo após deixar o serviço público pode um servidor público começar a atuar como lobista perante seus excolegas? Um ex-consultor de empresas produtoras de material bélico é uma alternativa legítima para ocupar o cargo de Secretário da Defesa? Além dos seus supostos excessos com bebida e mulheres, a teoria por trás da rejeição pelo Senado, em 1989, do nome de John Tower para Secretário da Defesa, era que os incentivos de sua carreira privada torná-loiam incapaz de agir sempre no interesse público. De forma semelhante, na sua campanha presidencial de 1992, Ross Perot freqüentemente atacou o sistema que permitia que servidores públicos deixassem seus cargos e fossem trabalhar para lobbies estrangeiros. A linguagem do debate sobre ética pública soa diferente do que nas teorias descritas acima, mas a preocupação é a mesma: a influência relativa que a iniciativa privada pode exercer sobre os formuladores de políticas através da manipulação dos seus incentivos de carreira.

Em resumo, teoria de Estados capitalistas e desenvolvimentistas, novo institucionalismo e escolha racional, bem como debates sobre ética no governo, todos têm mais ou menos as mesmas hipóteses explícitas sobre as motivações dos burocratas e, portanto, precisam, para confirmação e detalhamento, exame empírico cuidadoso das fontes e da força das preferências e autonomias burocráticas. A análise comparativa de padrōes de carreira é um item necessário na agenda dessa pesquisa.

\section{Recrutamento}

- Grau de Instrução

Nas últimas décadas, quase todos os burocratas de alto nivel em todos os cinco países ingressaram em suas carreiras públicas com um diploma universitário nas mãos. Essa exigência para o ingresso já reduz o universo de candidatos, especialmente no Brasil e no México. Além disso, a origem social predominante das elites administrativas em todo o mundo é clevada, e apresenta pequena variação entre os países aqui 
estudados.' A educação universitária é um outro fator determinante do tipo de elite que ingressa no Estado. Quanto menor o número de universidades das quais o Estado recruta, maior a probabilidade dos egressos dessas universidades pensarem de forma semelhante e atribuirem grande importância ao papel centralizador do Estado, e mais coesa e homogênea será a elite burocrática ${ }^{10}$ E quanto mais competente c rigorosa for a universidade, tanto mais os egressos terāo a probabilidade de legitimar-se como uma elite de mérito.

Os dados da Tabela 1 dão uma idéia aproximada da estreiteza do funil educacional. ${ }^{.1}$
No Japāo, a grande maioria dos servidores do topo da hierarquia freqüentaram as mesmas universidades, e a concentração é alta mesmo nos niveis inferiores. Os números da França para egressos das principais faculdades de direito e de ciências políticas e da ENA provavelmente mostrariam uma concentração um pouco menor, porém nāo há dados comparativos disponíveis. ${ }^{12} \mathrm{Na}$ França, no Japão, e em menor grau no México, a probabilidade de alguém tomarse um burocrata de elite é determinada cedo. Conseguir entrar para as escolas que encaminham jovens para a elite do Estado exige pais que vivam na capital e tenham os meios e o compromisso de prover a rigorosa

- ABERBACH et al., op. cit., p. 47 escreve que "a pesquisa sobre a composição das elites em praticamente todos os países, mostrou, especialmente nas posiçōes mais alıas da hierarquia política e administrativa, uma representação mals do que proporcional de pessoas do sexo masculino, instruidas, de alto nível social." Para informaçōes adiciona is sobre a origem social das elites burocráticas no México, veja CENTENO, Miguel. The New Cientificos (Tese Dout., Univ. Yale, 1990), p. 161-174 e SMTTH, op. cit., p. 104.132; no Brasil, veja DALAND, op. cit., p. 269-277; no Japão, KUBOTA, Akiro. Higher Civil Servants in Postwar Japan. Princeton: Princeton University Press, 1969 e KOH, B.C. Japan's Administrative Elite. Berkeley: University of California Press, 1989, p. 3, 21.22; e nos Estados Unidos, França e outros paises curopeus, ABERBACH et al., op. cit., p.46-83 e ARMSTRONG, op. cit.

10 - RUESCHEMEYER, EVANS. Op. cit., p. $51-59$.

II - De maneira geral, recomenda-se cautela na comparaçäo dos dados deste arił go. Os dados muitas vezes originam-se de estudos de períodos diferentes que usam diversas metodologias. Quando haviam várias fontes disponíveis, eu usei aquelas que cobriam os 150-200 administradores mais altamente posicionados, tinham valores razoavelmente recentes e cobriam períodos mais longos. Nesta breve análise de estática comparada, muitas nuances e mudanças sāo necessariamente negligenciadas, como por exemplo a recente mudança nas contrataçōes no México, de universł dade públicas para universidades particulares.

12 - Veja SUlEIMAN, Era. Politics and Burcaucracy in France. Princeton: Princeton University Press, 1974, p. 72-109; BIRNBAUM, Pierre. The Heights of Power. Chicago: Chicago University Press, 1982; KOH, op. cit., p. 116-119 e SIWEK-POUYDESSAU, Jeanne. Le Personnel de Direction des Ministères. Paris: Armand Colin, 1969. 


\section{TABELA I \\ PROPORÇÃO DE ADMINISTRADORES DE ELITE \\ DAS MELHORES UNIVERSIDADES \\ (PERCENTUAIS)}

\begin{tabular}{|c|c|c|c|c|}
\hline Especifica çào & $\begin{array}{c}\text { Melhor } \\
\text { universidade }\end{array}$ & $\begin{array}{c}\text { Duas } \\
\text { melhores } \\
\text { universidades }\end{array}$ & $\begin{array}{c}\text { Très } \\
\text { melhores } \\
\text { universidades }\end{array}$ & Número \\
\hline Japàox & 83 & 89 & & 167 \\
\hline Méxicob & 64 & 69 & 72 & 654 \\
\hline Brasile & 22 & 35 & 46 & 263 \\
\hline EUAd & 8 & 14 & 20 & 1.032 \\
\hline
\end{tabular}

Nota: Melhor ê uma distinçào quantitativa: as escolas que produzem o maior númxero de servidores de clite.

- Todos os 22 vice-ministros administrativos e 145 chefes de departamento em 1986 (calculado de KOH, p. 141, tabela 22). A methor universidade é a de Tóquio, seguida pela de Kioto. Para os servidores de nivel de assistente de chefe de escritório ou superior, a proporçào de formados pela Universidade de Tóquio variou entre $81 \%$ e $86 \%$ de 1949 a 1986 (KOH, p. I40, tabela 21 ). Lin outra pesquisa sobre burocratas de alto e médio nivel em 1976-78, a proporção das duas melhores universidades foi de 85\% (N=251, MURAMATSU C KRAUSE, p. 126)

- Valor médio para os principais 69 a 144 líderes políticos nos sete governos de 1935 2 1976 (CAMP, Roderic. Mexico's Leaders. Tucson: University of Arizona Press, 1980, p. 78-79). A melhor universidade fol a UNAM, scguida pela Academia Militar Nacional, c a Escola Nacional de Agricultura. Em 1983, 56\% de uma amostra muito maior eram cgressos da UNAM (CENTENO. p. 180).

- Servidores que ocuparam as posiçōes mais altas na burocracia económica entre 1964 e 1986 (para a metodologia de pesquisa, veja SCHNEIDER, Apêndice A). A melhor universidade é a Universidade Federal do Rio de Janeiro, seguida pela Universidade Federal de Minas Gerais e pela Universidade de São Paulo.

d Percentual de executivos políticos nas 180 posiçōes mais altas (1933-65) que cursaram universidade. As três melhores escolas foram Yalc, Harvard e Princeton (STANLEY, David T., MANN, Dean, DOlG, Jameson. Men Who Govern. Washington: The Brookings Institution, 1967, p.21, 126). Somente $8 \%$ de uma amostra mais abrangente cursaram as três melhores universidades $(N=7,628$, WARNER, W. Lloyd, VAN RIPER, Paul, MARTTN, Norman, COLLINS, Orvis. The American Federal Executive. New Haven: Yale University Press, 1963, p. 132) 
educação pré-universitária necessária para passar nos exames de admissão. Muitas vezes, $\mathrm{cm}$ uma tendência de reprodução sociológica, os próprios pais sāo burocratas de elite. ${ }^{13}$

Ao ingressar na Faculdade de Direito da Universidade de Tóquio, na ENA, ou na Faculdade de Economia da UNAM, a maioria dos cstudantes sabe que passará a sua carreira servindo ao estado. Por exemplo, dos 178 egressos da Faculdade Nacional de Fconomia (na UNAM) de 1929 a 1951, 93\% seguiu carreiras públicas. Entre um terço e metade dos egressos da Faculdade de Direito da Universidade de Tóquio na década de 70 que se empregaram imediatamente após a formatura foram trabalhar na burocracia. Na França, nove entre dez burocratas de elite disseram que se decidiram por uma carreira no governo antes de concluir o curso superior (44\% decidiu-se antes de concluir o curso secundário)." Além disso, o currículo nessas universidades muitas vezes é projetado para inculcar e reforçar uma identidade de Estado, e muitas vezes os próprios professores são servidores de elite. ${ }^{15}$

No Brasil e especialmente nos Estados Unidos, o ingresso na clite é menos restrito. ${ }^{16} \mathrm{~A}$ educação superior é ainda um pré-requisito excludente, mas os servidores vêm de diversas universidades e estudam com colegas que na sua maioria seguem carreiras no setor privado. Os estudantes brasileiros e norte-americanos não estudam em cursos que levam direto ao topo da burocracia e também não recebem uma formação como futuros membros da elite do Estado. A segunda Comissão Hoover concluiu que "as capacidades que sāo tão essenciais aos ocupantes de cargos em co-

13 - Mais de um terço dos 253 egressos da ENA que ingressaram nos grands corps de 1953 a 1963 tinham pais nos mais altos escalōes do serviço público. BIRNBAUM, op. cit., p. 69. No Brasil, um quinto dos servidores de alto escalão tinham pais no serviço público. DAl.AND, op. cit., p. 274. A proporçāo é semelhante aos burocratas de antes da guerra no Japão. KOH, op. cit., p.22, Tabela 3.

14 - CAMP, Roderic A Mexico's Leaders: Their Education and Recruitment. Tucson: University of Arizona Press, 1980, p. 161; JOHNSON, Chalmers. MITI and the Japanese Miracle. Stanford: Stanford University Press, 1982, p. 60-61; SULELMAN. Politics. Power and Bureaucracy in France, op. cil., p. $118, \mathrm{~N}=90$.

B - SUleLMAN. Elites in French Society, op. cit., 119.

16 - Nos termos de Aranstrong, p. 1819, 232-233, a França, o México e o Japão rendem na direçāo de um modelo extremamente rigoroso de recrutamento, enquanto o Brasil lembra um modelo mais aberto, 20 qual os Estados Unidos se aproximam. 
missão não são sistemalicamente desenvolvidas em nenhum lugar na vida norteamericana. A sociedade norte. americana não formou exe. cutivos para a liderança política."17

Lssas diferenças com respeito a recrutamento e treinamento também afetam a forma como aqueles de fora do Estado vêem os burocratas de elite. Na França e no Japāo é difícil ingressar no campo de adestramento burocrático na universidade, o curso é muito competitivo, e a subseqüente colocação profissional depende em muito do desempenho em relação ao resto da classe. No México, os egressos de universidades do Primeiro Mundo recen temente começaram a fornecer os recursos humanos para o tipo de recrutamento afunilado e a marca de distinção conferida pela ENA ou pela Universidade de Tóquio. Em sociedades que respeitam as elites de mérito, o recrutamento baseado no desempenho acadêmico pode aumentar a legitimidade de uma burocracia poderosa: uma república de estudantes brtbantes, como tem sido chamada na França. ${ }^{18}$ Esses servidores são os mais inteligentes no país e sobreviveram às universidades mais dificeis; eles devem saber o que fazem.

No Brasil, tem havido uma ampla aceitação de soluçōes tecnocráticas decretadas pelos servidores públicos, mas isso não significa que os administradores de elite são geralmente considerados como possuindo inteligência superior. Apesar disso, o prestígio e a competência presumida dos burocratas de elite no Brasil provarelmente não são tão baixos quanto entre seus pares nos Estados Unidos, onde cerca de metade dos respondentes em pesquisas periódicas na década de 70 , achavam que "muitos [servidores públicos] parecem não saber o que estão fazendo." 19

Em resumo, os servidores brasileiros e norte-americanos e os Estados que servem têm menor probabilidade de se

\footnotetext{
7 - Citado em MANN, Dean. The Assistant Sccretaries. Washington D.C.: The Brookings Institution, 1965, p. 8.

18 - ANTONI, Pascal, ANTONI, Jean-Dominique. Les Ministres de la vi République. Paris: 1976, citado em BIRNBAUM, op. cit., p. 65. Sulciman concluí que "o critério do mérito ... é a base principal da legitimidade da elite francesa." SULELMAN, Ezra $N$. "Sclf-lmage, Legitimacy and the Stabllity of Elites". British Journal of Political Science, 7, abril de 1977, p. 214.

19 - DOWNS, Gcorge W., LARKEY, Patrick D. The Scarch for Government Efficiency: From Hubris to Helplessness. Philadelphia: Temple University Press, 1986, p. 10.
} 
beneficiarem da presunçāo de competência que aumenta a autoridade e o poder de decisāo da burocracia no Japão, no México e na França. As elites de mérito nesses últimos países têm maior probabilidade de desenvolver, através de convivência comum, preferências distintamente centralizadoras, e em razāo do prestigio de que gozam, eles provavelmente darāo maior peso a suas próprias preferências. Essa suposiçāo de competência pode ter um efeito indireto sobre o isolamento, desencorajando os atores sociais de patrocinar preferências contrárias àquelas expressas pelos burocratas de elite.

\section{Circulação}

\section{D} de meio de carreira afetam as preferências burocráticas, embora de formas diferentes. Em primciro lugar, se os servidores passam a sua vida adulta no serviço público, é mais provável que desenvolvam preferências fortes que divergem daquelas da sociedade. ${ }^{20} \mathrm{Fm}$ segundo lugar, se os servidores trabalham em vários órgãos diferentes tratando de quesıces variadas, cles têm menor probabilidade de estabelecer vínculos estreitos com seus clientes ou de adotar os seus pontos de vista. Além disso, os padrōes de mobilidade dentro do Estado moldam as principais lealdades dos burocratas e sāo portanto um critério importante na identificaçāo de quais instituições têm provavelmente maior importância. De maneira geral, quanto menos os servidores circulam entre os setores público e privado, e quanto mais circulam dentro do Fistado, mais oportunidades terão para desenvolver preferências claramente centralizadoras.

Ao alcançarem as posiçōes mais altas dentro do Estado, a maioria dos servidores $\mathrm{em}$ todos os países (salvo os executivos políticos nos Fstados Unidos) passaram trêsquartos ou mais de suas carreiras no governo. As carreiras dos burocratas de clite no Japão c no México são ainda mais restritas ao setor público (até uma aposentadoria precoce). No Japão, os servidores de elite ingressam na burocracia diretamentc da universidade, $\mathrm{c}$ a entrada lateral $\mathrm{cm}$ uma idade mais avançada é praticamente impossivel, o que exclui experiência prévia importante no sctor

20 - NORDLINGLR, op. cit., p. 32. 
privado. ${ }^{21} \mathrm{O}$ México possui poucas restriçōes à entrada lateral, e muitos servidores de elite ingressam em um nível bastante elevado. ${ }^{22}$ Entretanto, eles raramente vêm de carreiras na iniciativa privada. No nivel mais alto, somente 10 por cento dos ministros de gabinete, que na sua maior parte progrediram dentro da burocracia, têm cxperiência a nivel gerencial no setor privado. ${ }^{23}$ Por isso, a maior parte dos altos funcionários nesses paises têm a oportunidade, no scu isolamento ocupacional, de transformar-se cm um grupo social distinto e de desenvolver preferências diferentes das da sociedade.

Dentro do Estado, os padrôes de carreira diferem de forma mais significativa entre os cinco países. A Tabela 2 fornece uma indicação aproximada dos níveis de circulação: a proporção de servidores que trabalham para vários ministérios. Onde há dados comparáveis disponiveis, tais indicadores provavelmente colocariam o Japão em níveis baixos de circulação. Esses padrōes de circulação interna podem ter um profundo impacto sobre preferências, políticas burocráticas, c tendências centrífugas den tro do Estado e por isso merecem um exame qualitativo mais apurado.

No Japão, os servidores ingressam no ministério e tem a expectativa de permanecer por toda a sua carreira pública naquele ministério e nos órgãos a ele associados. Os novatos promissores recebem nos primeiros anos tarefas temporárias em uma séric de departamentos, faxem aquecimento para que se familiarizem e tenham uma visão geral do ministério. No meio de sua carreira, aqueles que estāo a caminho do topo muitas vezes trabalham para os departamentos mais importantes do ministério. ${ }^{24}$ Nos Estados Unidos, os servidores públicos movem-se ainda menos: "somente um servidor público graduado bem sucedido fa\% mais que uma mudança de departamento ou de órgão durante uma vida inteira no

\footnotetext{
- JOHNSON, Chalmers. "The Recmployment of Retired Government Bureaucrats in Japanese Big Business". In: Asian Survey, 14, novembro de 1974, p. 960; KOH. op. cit., p. 1 . 55.

22 - CENTLNO, op. cil., p. 195, 199-200.

23 - CAMP. Roderic A. Entrepreneurs and Politics in Twentieth-Century Mexico. New York: Oxford University Press, 1989. p.82.

24 - JOHNSON. MIT1 and the Japanese Miracle. Op. cit., p.62, 74, 78; KOH, op. cit., p. $127 \cdot 135$.
} 
serviço público. ${ }^{25} \mathrm{Na}$ França, as carreiras dos servidores graduados são geralmente limitadas a um único ministério. Entretanto, os grand corps (e os membros mais graduados do corps) influenciam mais as promoçōes do que o ministério". ${ }^{26}$

A mobilidade no Brasil e no México é muito maior: os siervidores mudam de órgãos ou de ministérios a cada quatro ou cinco anos. ${ }^{27}$ No México, a mobilidade das carreiras depende em muito das camarillas, grupos informais que se formam à volta de adversários concorrentes ao poder. No Brasil não há fator comparável que organize a circulação; alguns servidores permanecem em um único ministério, outros unem-se a grupos informais tipo camarilla, e outros apenas circulam. ${ }^{28}$

Esses padrôes de circulação determinam então os incentivos para as principais lealdades dos burocratas ambiciosos. Essas lealdades, por sua vez, deverāo afetar o conteúdo de caráter centralizador das preferências, as bases dos conflitos entre órgãos, e a probabilidade de coalizōes fortes entre empresas e burocratas, algumas rezes chamadas de triângulos de ferro, ou, no Brasil, de anéts burocraticos. ${ }^{29}$ Os burocratas japoneses e franceses têm alta probabilidade de desenvolver uma orientação relativamente ampla, por pertencerem e serem leais às amplas familias de ministérios e aos grands corps, respectivamente. Os burocratas de elite devem lealdade, em primeiro lugar, a essas instituiçōes c não ao Esstado como um todo ou a órgãos específicos. E mais provável que os conflitos dentro da burocracia girem em tomo de cerca de uma dúzia de ministérios ou corps importantes, embora, dada a organizaçāo funcional, um corps ou ministério seja geralmente dominante em uma certa área de políticas.

Quando, como nos Estados Unidos, as carreiras sāo restritas a departamentos ou órgãos espe-

\footnotetext{
25 - McGREGOR JR., Eugene B. "Politics and the Career Mobility of Bureaucrats". American Political Science Review, 68, março de 1974, p. 24, $\mathrm{N}=557$.

26 - Sulejman. Politics, Power and Bureaucracy. Op. cit., p. 147-148.

27 - SCHNEIDER, op.cit., p. 27-28; SMTH, op. cit., p. 150-151.

28 - CENTENO, op. cit., p. 224-259; CENTENO, Miguel Angel, WELDON, Jeffey. A Snall Circle of Friends. Trabalho apresentado nas reuniōes da Associação de Estudos Latino-Americanos, Washington, D.C., 1991; CAMP, Roderic. "Camarillas in Mexican Politics". Mexican Studies/Estudios Mexicanos, 6, Inverno de 1990, p. 85-108. Sobre o Brasil, veja SCHNELDER, op. cit., p. 23-71.

- CARDOSO, Fernando Henrique. Autoritarismo e Democratização. Rio de Janeiro: Paz e Terra, 1975, p. 181-183.
} 


\begin{tabular}{|c|c|c|c|c|}
\hline \multirow{3}{*}{ Espocifilcação } & \multicolumn{4}{|c|}{$\begin{array}{l}\text { TABELA } 2 \\
\text { S CARREIRAS DOS BUROCRATAS DE ELITE }\end{array}$} \\
\hline & \multicolumn{2}{|c|}{$\begin{array}{l}\text { Percenfual daquales que } \\
\text { permanoceram } 25 \% \text { ou } \\
\text { male de sua vida adulia } \\
\text { fora do governo nacional }\end{array}$} & \multicolumn{2}{|c|}{$\begin{array}{l}\text { Percentual daqueles que } \\
\text { serviram om um minis- } \\
\text { Iório diferente do afual }\end{array}$} \\
\hline & Feroentuad & $(\mathbf{N})$ & Porcentual & $(\mathbf{N})$ \\
\hline França & $37^{\circ}$ & (75) & $19^{b}$ & - \\
\hline Estados Unidos & & & & \\
\hline - servidores públicos & 30 & $(64)$ & 22 & (64) \\
\hline - cxecutivos políticos & 78 & $(60)$ & 18 & $(61)$ \\
\hline Brasil & $38^{c}$ & (232) & $75^{d}$ & (232) \\
\hline México & - & - & 72 & $(1.278)$ \\
\hline
\end{tabular}

Fonfes: para os Estados Unidos, de ABERBACH ct al. Burcaucrats and Politicians in Western Democracies, "Politlcal executives and presidential appointecs", p.71. Para o México, CENTENO, p. 206.

- ABERBACH et al., p.71.

b SIWEK-POUYDESSEAU, citado em SULELMAN. Politics, Power and Bureaucracy in France, p. 148, para servidores promovidos 2 diretor entre 1946 e 1969. Os números não foram informados.

- ABERBACH et al. Os dados foram obtidos de entrevistas com burocratas em atividade e indicam o periodo anterior no setor privado. Meus dados originais sobre o Brasil também incluem emprego no setor privado para alguns poucos servidores públicos após 2 sua aposentadoria do serviço público.

- Percentual dos que trabalharam para très ou mais órgãos diferentes. Algums órgāos ligados a um mesmo ministério eram suficientemente distintos para que eu contasse as movimentaçōes entre eles como mudança de órgäos. Em compensei fazendo os cálculos mais comparáveis usando a proporção de quem trabalhou em très ou ma is órgāos (veja Schneider, Apèndice A), o que resulta cm uma estimativa conservadora do número dos que trabalharam para mais de um ministério. 
cificos, as lealdades tendem a ser mais locais, e, correspondentemente, é mais alta a probabilidade dos burocratas adotarem os pontos de vista de suas clientelas tomar-se nativo. ${ }^{30} \mathrm{As}$ lealdades locais, por sua vez, exacerbam as tendências centrífugas dentro da burocracia que podem enfraquecer os Estados diretamente, mediante a diminuição de sua capacidade de ação e ampliar a influência de atores da sociedade, uma vez que os servidores podem ser tentados a chamar aliados externos. Os servidores que ficam nos mesmos órgãos por anos a fio c têm relacionamentos de longa data com parlamentares e com grupos de interesse são os que formam os trikingulos de ferro."

Em contraste, a alta rotatividade no Brasil c no México favorece o isolamento burocrático, porque o acesso à formulação de políticas e à influência sobre as mesmas muitas vezes depende de relaçōes informais pessoais nos anéis burocráticos. A alta rotatividade desarticula essas ligaçōes pessoais e nega aos interesses empresariais externos um ponto de apoio permanente dentro da burocracia, dessa forma aumentando a autonomia burocrática ao longo do tempo, mediante o rompimento perió dico dos vínculos informais entre o Isstado e a sociedade.

Lideres em outros Estados e outros órgãos reconheceram esse efeito e promoveram-no deliberadamente. Quando o governo central nomeia servidores locais, muitas vezes sāo nomeadas pessoas de fora da região e são removidas depois de uma breve permanência. Os governos republicanos franceses fizeram disso prática comum, assim como os imperadores brasileiros. ${ }^{32}$ lissa rotatividade tem um duplo efeito sobre o controle central c a autonomia burocrática: previne o contato íntimo, duradouro entre os servidores e os interesses locais, e assegura que os servidores são leais, antes de tudo,

\footnotetext{
30 - Veja PElLES, B. Guy. "The Problem of Bureaucratic Government". Journal of Politics, 13, fevereiro de 1981, p. 68.

31 - Para uma argunkentaçao recente, veja: SMLTH, Hedrick. The Power Ganc. Nova Iorque: Ballantine Books, 1988, p. 173-183.

32 - Sobre o Serviço Florestal dos Lstados Unidos, veja KAUFMAN, Herbert. The Forest Ranger. Baltimore: The Johns Hopkins University Press, 1960. O Departa. mento de Estado dos Estados Únidos e a maioria dos outros serviços diplomáticos promove a rotatividade dos servidores através de vários países pelo mesmo motivo. Durante o periodo $1877-1958$, os administradores territoriais franceses permanceram uma média de 2.6 anos em seus cargos. ARMSTRONG, op. cit., p. 255. No século XIX, a provincia brasileira de Minas Gerais teve 122 presidentes em 65 anos; a média de permanência no cargo foi de $\mathrm{um}$ pouco mais de seis meses. SCHWARTZMAN. Simon. As Bases do Autoritarismo Brasileiro. Rio de Janciro: Campus, 1982, p. 92.
} 
às autoridades centrais que controlam as suas carreiras.

Nảo é suficiente apenas examinar as estruturas e as organizaçōes do Estado; nós também precisamos saber como as carreiras públicas entram e saem delas. As organizaçōes mais fortes ou as entidades maximizadoras do orçamento não são órgãos ou agências individuais mas sim amplas familias ministeriais no Japão, grands corps na França, e camarillas no México. Nos Estados Unidos e no Brasil o quadro fica complicado pelas múltiplas trajetórias de carreira e portanto múltiplas lealdades, miuitas vezes sobrepostas. Alguns servidores ligam-se a seus órgãos, outros amalgamam-se em panelinhas pessoais tipo camarilla, e outros pertencem a alianças políticas mais amplas (especialmente grupos regionais) que abrangem os limites da bu rocracia. Essas grandes variações em circulação e, portanto, nas lealdades nos cinco países, mostram que os componentes principais das burocracias variam substancialmente de um país para o próximo.

\section{Promoção}

O poder discricionário de contratar e demitir tem um impacto direto e decisivo sobre carreiras e incentivos. As pessoas ou as normas que controlam o acesso aos postos mais altos determinam se os nomeados devem seus cargos ao procedimento universal (normas internas), ao Executivo ou a outras forças externas sociais e políticas. As variaçōes nos processos de nomeação nos cinco países é surpreendente. O primeiroministro do Japão nomeia dezenas de servidores de al to escalāo, o presidente da França escolbe centenas; o presidente dos Estados Unidos seleciona milhares; c os presidentes do Brasil e do México indicam dezenas de milhares de servidores. ${ }^{33}$ Embora milhares de servidores nomeados no Brasil e no México não tenham impacto sobre as políticas, e enquanto as principais promoções por mérito no Japão e na França são sem dúvida noticiadas, a mistura predominante de critérios de promoção afeta profundamente as bases da autonomia burocrática. Além das diferenças transnacionais nos poderes formais de nomeaçāo, os presidentes e primeiro-min istros também buscam candidatos a nomeação em fontes diferentes: os presidentes norte-americanos dependem de talentos do setor privado, enquanto os líderes

33 Veja SCIINEIDER, op. cit., p. 70. 
políticos em outros países dependem principalmente de burocratas seniores (se nāo para ministros, certamente para o escalâo imediatamente inferior).

Uma das principais fontes de preferências divergentes por parte do Estado pode ser encontrada no fato de que servidores graduados passam a maior parte de seu tempo com outros servidores graduados. O impacto disso é bastante reforçado quando a promoção de um servidor depende de procedimen tos formais e da avaliação de um outro servidor a respeito de seu desempenho. Além de promover mais preferências de caráter centralizador estatal, a promoção por mérito priva os atores sociais c políticos da alavanca mais poderosa para influenciar o comportamento burocrático: promoção (ou interrupção) de carreiras. A colocaçāo do principal interesse pessoal dos burocratas fora do alcance de atores externos aumenta enormemente a sua independência. ${ }^{34}$ Finalmente, a promoção por mérito também aumenta o prestígio e a reputaçāo de competência técnica dos servidores. Os burocratas por mérito na França, Japão e nos Estados Unidos (somente os servidores públicos de carreira) também gozam de maior autonomia em relação aos seus superiores políticos e às elites econômicas porque as suas carreiras estāo protegidas.

Os burocratas brasileiros e mexicanos não gozam de tal isolamento institucional. Entretanto, os presidentes desses países podem usar seu enorme poder de nomeação para aumentar a autonomia da burocracia. Quando eles nomeiam servidores sem ligações ou bases de apoio externas, estes servidores dependem do presidente, mas ficam isolados de outros atores políticos ou sociais. Entretanto, a centralização das nomeações significa que a burocracia do Executivo não tem força independente com respeito ao presidente. E uma casca administrativa, $\mathrm{e}$ a sua autonomia depende da força do presidente. A cada

\footnotetext{
34 - Fred Riggs observou que a promoçāo por mérito em países em desenvolvimento poderia deslocar perigosamente o poder político em favor da burocracia. RIGGS, Fred. "Bureaucrats and Political Development". Em: IaPALOMBARA, Joseph, ed. Bureaucracy and Political Development. Princeton: Princeton University Press, 1963, p. 127-129. Nos Estados Unidos, a discussāo continua sobre como a promoçżo por mérito enfraquece o controle presidencial sobre a burocracia. Veja MOE, Terry M. "The Politicized Presidency". Em: CHUBB, Johh E., PETERSON, Paul E., eds. The New Direction in American Politics. Washington D.C.: Brookings, 1985; e ABERBACH, Jocl D., ROCKMAN, Bert A. Mandates or Mandarins?, trabalho preparado para a reuniào da Associação Ocidental de Política Social, Anaheim, Califórnia, 1987.
} 
sucessāo presidencial existe uma luta pela autonomia isolamento burocráticos. No Brasil e no México, muitas vezes faz mais sentido substituir a força do governo ou do presidente pelo isolamento burocrático ou a autonomia do Estado. ${ }^{35}$

O poder de nomear é formalmente uma prerrogativa do Executivo, mas, informalmente, é geralmente um item a ser negociado com grupos de apoio poderosos. Quando são muitas as nomeaçōes e o L.egislativo é forte (como nos Estados Unidos e no Brasil sob regime civil) os parlamentares podem tornar-se participantes importantes na promoção de burocratas. Na medida em que os parlamentares dependem dos empresários ou são receptivos a seus interesses, os capitalistas obtém influên cia indireta sobre as carreiras burocráticas.

Para os Executivos fracos, esses enormes poderes de nomeação podem ser uma grande desvantagem. Os presidentes c primeiro-ministros eleitos por pequena margem de votos, os pouco populares ou aqueles de legitimidade questionável têm uma enorme tentação de distribuir cargos em troca de apoio político. Tais representantes nomeados aceitam os cargos e prometem apoio em troca de carta branca para fazer o que quiserem em suas funções. Eles são os representantes diretos das forças políticas e sociais externas e provavelmente utilizar-se-ão de seus cargos para atender às necessidades dos grupos que lhes dão sustentação. Nessa situação, o Executivo será privado do controle com maior probabilidade do que na situação de promoção por mérito, e os grupos sociais representados despojarão a burocracia de seu isolamento.

\section{Descida do céu}

- s padrōes de desligamento do serviço público são, potencialmente, o mais poderoso dos cin co componentes da carreira na determinação das relaçōes entre o empresariado e os burocratas, porque os servidores que se encontram próximos da aposentadoria estão no nível máximo de seu poder e ao mesmo tempo mais alertas do que a qualquer outro tempo com respeito a oportunidades no setor privado, uma vez que sabem que em breve estarão procurando

35 - Veja GEDDES, "Butlding State Autonomy in Brazil", op. cit. 
emprego. ${ }^{36} \Lambda$ questão é até que ponto o emprego após o serviço público condiciona as preferências expressas e o comportamento dos burocratas em final de carreira. Segundo Heclo, "certamente não é cínico sugerir que aqueles que ocupam cargos por indicação politica, preocupem-se, como todos nós, com o amanhã quando se trata de empregadores em potencial." 37 Se os servidores graduados geralmente ingressam diretamente em posiçōes executivas em empresas privadas que eles fiscalizavam quando servidores públicos, então podemos esperar que, ainda na atividade pública, cultivem laços com empregadores em potencial e que procurem tratar de seus principais interesses. Se, no outro extremo, a maioria dos servidores graduados, ao aposentar-se da função pública, ingressar $\mathrm{cm}$ universidades, em organ izações sem fins lucrativos, em atividades de consultoria de tempo parcial ao governo, ou cm empresas não relacionadas com sua atividades anterior, entāo terão menos incentivos para acomodar os interesses das indústrias que supervisionam.

\section{A maioria dos observadores} concorda que a grande movimentação do topo da bu rocracia para dentro de grandes empresas, conhecido como amakudari (descida do céu) em japonês, deve logicamente alterar o comportamento e a orientação dos burocratas mais antigos em seus últimos anos no serviço público. Mas existem poucas provas concretas disso. Nas agências regulatórias norte-americanas, onde está sempre presente a preocupação a respeito do conflito de interesses gerado pelo amakudari (o suborno de efeito retardado, na linguagem popular), um estudo tentou examinar a questão indiretamente, indagando se as preferências ou o comportamento do servidor ocupando cargo público tinham algum impacto sobre a obtenção, mais tarde, de emprego na iniciativa privada. Quase a metade dos burocratas respondeu que $\operatorname{sim}^{38}$

\footnotetext{
36 - Isto é também onde aqueles que buscam confirmar a existência de uma clite de poder concentram sua atenção. Sobre os Estados Unidos, veja por exemplo FRETTAG. Peler J. "The Cabinet and Big Business". Social Problems, 23, dezembro de 1975, p. 137. 152; sobre o México, veja CAMP. Entreprencurs and Politics, op. cit., p. 77-103.

37 - HECLO, Hugh. "The In-and-Outer System". Political Science Quarterly, 103. primavera de 1988 , p. 52.

38 - QUIRK, Paul J. Industry Influence in Federal Regulatory Agencies. Princeton: Princeton University Press, 1981, p. 149, $\mathrm{N}=47$. Quasc todos os servidores também alegaram que tais consideraçóes não afetavam seus próprios pontos de visıa. Dada a improbidade de admitir a influência, é provável que as taxas de respostas positivas estejam subestimadas em ambos os casos. Sobre o Japảo, veja CURTLS, I_ Gerald. "Big Business and Political Infuence". Em: VOGEI. Era F., ed. Modern Japanese Organization and Decision-Making. Berkeley: University of California Press, 1975. p. 1.1-\$5.
} 
O outro efeito importante do amakudari nos padróes de acesso é mais claro. Quando os servidores deixam seus cargos públicos, eles levam consigo experiência, conhecimento e contatos informais. Dependendo de onde essas habilidades aportam na sociedade, elas podem alterar o acesso e a interação entre a burocracia e outros atores sociais e politicos. Se os burocratas acabam ocupando cargos em grandes empresas e escritórios especializados $\mathrm{em}$ lobby, eles podem ampliar o acesso c a influcencia do empresariado.

A ida de burocratas japoneses seniores para o setor privado tem sido grande no periodo pósguerra e está melhor documentado do que em outros países. ${ }^{39}$ Os servidores públicos graduados aposen tam-se em tomo de 55 anos de idade. ${ }^{40} A$ maioria deles segue trabalhando em empresas públicas, empresas privadas, associaçōes de classe patronais, ou na política (cm 1986, um quarto dos membros do Partido Liberal Democrata na Câmara Baixa, bem como um terço do membros da Câmara Alta eram ex-burocratas). ${ }^{41} \mathrm{~A}$ cada ano, centenas de burocratas de alto escalão passam a trabalhar $\mathrm{em}$ empresas privadas. ${ }^{42}$ De 1949 a 1976 , quatorze ou quinze viceministros do Ministério do Comércio Internacional e da Indústria (MIT'D passaram a ocupar cargos executivos em grandes empresas. ${ }^{43}$ Dados parciais indicam que estas movimentaçōes Japanese Big Business", op. cit., e MITI and the Japanese Miracle, op. cit., p. 65-72; BLUMENTHAL, Tuvia. "The Practice of Amakudari within the Japanese Employment System". Asian Survey, 25, março de 1985, p. 310-321: KOH, op. cit., p. 234-246; c CAI.DER, Kent E. "Elites in an Equalizing Role". Comparative Politics, 21, julho de 1989. p. 379.404. As carreiras pós-serviço público parecem ser importantes com respeito às questóes relativas à autonomia burocrática, mas apesar disso nāo existe um volume considerável de dados empíricos. A maioria dos estudos sobre administradores de elite investigam servidores $\mathrm{em}$ atividade que são muito mais fáceis de identificar, abordar e pesquisar em um curto espaço de tempo. Os custos de pesquisa mu ito mais altos para descobrir para onde vao os ex-burocratas significa que temos muito ma is dados sobre de onde os servidores graduados vêm, e muito mais teorização sobre o impacto da origem social e das relaçōes de a mizade. Essa influêncla de custos na bibliografia é lamentável, uma vez que os padrōes de emprego pós-serviço público podem ter mais influência sobre o comportamento de servidores poderosos com idades entre 50 e 60 anos do que o nível social de sua familia de origem e a formaçào universitária de há muiras décadas.

40 - JOHNSON. "The Recmployment of Retired Government Bureaucrats in Japanese Big Business", op. cit., p. 953; KOH, op. cit., p. 234.

41 - KOH, op. cit., p. 242.

42 - Veja BLUMENTHAL, op. cit., p. 312-316.

43 - JOHNSON. MITI and the Japanese Miracle, op. cit., p. 72, a partir da Tabela 6. 
resultaram em uma população significativa de burocratas no setor privado. Em um estudo do MrII, mais de um terço dos presidentes de empresa cram amakudari. ${ }^{44}$ Nos meados da década de 60 , cinco das seis grandes siderúrgicas tinham ex-burocratas do MIII no seu Conselho de Administração." Fntretanto, a maioria dos servidores públicos amakudari ingressa em empresas mais isoladas de segunda linha. ${ }^{16} \mathrm{O}$ amakudart dá aos burocratas no Japão incentivos para ajustar suas preferências e ouvir os empresários por ocasiāo da formulação de políticas. ${ }^{47}$ Johnson cita "Relatores do MITI ... [que] argumen tam que um burocrata sábio irá usar seus anos como chefe de seção para gerar novas idéias e pressionar a comunidade empresarial para adotá-las, mas como chefe de departamento ele deve tomar-se submisso aos clientes do ministério com o objetivo de melhorar o scu proprio amakudari ${ }^{48}$ As empresas privadas não apenas contratam burocratas com décadas de experiência no governo; elas também se beneficiam de normas de hierarquia arraigadas. Im entrevistas com servidores do MrII c do Ministério das Finanças, Calder verificou que os servidores menos graduados "sentem quase unanimemente a necessidade de agir com cautela nos relacionamentos com os seus ex-colegas, servidores graduados aposentados, devido à incerteza do que estes poderão dizer em sigilo aos superiores que ainda trabalham no ministério." Apesar disso, o amakudari não promove a corrupçâo sistemática, mas, em lugar disso, contribui para a cooperação global entre empresariado e governo. ${ }^{49}$

Os burocratas de elite da França parecem seguir uma descida semelhante, embora menos sistemática, para o setor privado. Faltam dados completos, mas a pantouflage (mudança para o setor

\footnotetext{
41 - Citado em Blumenthul, op. cit., p. 317. Infelizmente Blumenthal nāo fornece o método de amostragem ou o valor de $\mathrm{N}$.

45 - JOHINSON. MMTI and the Japanese Miracle, op. cit., p. 268.

46 - CALDER, op. cit.

17 - JOHNSON. "The Reemployment of Retired Government Bureaucrats", op. cit., p. 961.

48 JOHNSON. MITI and the Japanese Miracle, op. cit., p. 67-68.

19 - CALDER, op. cit., p. 398; JOHNSON. MITI and the Japanese Miracle, op. cit. Escãndalos isolados revelam que a tentação de abusar está sempre presente. A opiniâo pública japonesa ficou duplamente chocada com o escândalo Recruit, quando foi revelado que treze ex-funcionários graduados da Nippon Telegraph and Telephone, bem como outros funcionários, tinham trabalhado para a Recruit. Economist, 12 de novembro de 1988, p. 31-32.
} 
privado) tornou-se generalizado durante a Quinta República. ${ }^{30} \mathrm{O}$ setor privado busca os membros dos grands corps pelo seu preslígio, treinamento, e, principalmente, por seus contatos dentro do Estado. ${ }^{51}$ Além disso, o setor privado busca a elite administrativa para ter voz política: "quase todos os portavozes de empresas de projeção nacional na França são ex. burocratas de elite. ${ }^{32}$ Os administradores de elite da França também ingressam na política: $14 \%$ dos deputados eleitos em 1973 tinham experiência anterior no serviço público (um acréscimo com respeito aos $6 \%$ no periodo 1945 58)..$^{53}$

Nos Istados Unidos o amakudari é muito diferente. O serviço público nāo lança ex-burocratas para posições executivas $\mathrm{cm}$ grandes empresas, e eles raramente ingressam na política. Para os ocupantes de cargos em comissāo, o serviço público é apenas um breve interlúdio, de cinco a dez anos, em uma carreira no setor privado. Historicamente, a maioria (55\%) vai para o setor privado e quase a metade destes retoma para as empresas das quais é oriundo. ${ }^{54}$ Além disso, o emprego na iniciativa privada parece depender muito mais de credenciais profissionais do que de experiência na administração pública. Em uma pesquisa de servidores nomeados pelo presidente, de Johnson a Reagan, somente $1,5 \%$ dos respondentes assinalaram "ampliando oportunidades de carreira de longo prazo" como uma das suas três maiores satisfaçōes no serviço público." Menos de $10 \%$ dos ocupantes de cargos em comissão que ingressaram no setor privado

so Mais da metade dos ministros que abandonaram a politica (1958 1974, $\mathrm{N}=37$ ) foram nomeados para os conselhos de administraçāo de cmpresas públicas e privadas. Do total de 28 ministros que obtiveram assento nos conselhos (tendo ou nāo abandonado a vida política), um terço havia sido servidor público no passado. BIRNBAUM, op. cit., p. 59, 61. ARMSTRONG, op. cit., p. 221 , observa que a pantouflage é especialmente comum entre inspecteurs de finances.

51 - SULELMAN. Elites in French Socicty. Op. cit, p. 111.

52 - Ibid., p. 242.

\$3 - AUBERT, Véronique. Etude sur le personnel politique français. Tese, Universidade de Paris V, 1973, citado em BLRNBAUM, op. cit., p. 48.

54 - N=984, STANLEY, David T., MANN, Dcan E., DOIG, Jameson W. Men who Govern: A Biographical Profile of Federal Political Executives. Washington, D. C.: The Brookings Institution, 1967, p. 74. O percentual real é mais alto porque $13 \%$ do total dos pesquisados ainda estava $\mathrm{em}$ atividade.

ss - BRAUER, Carl. "Tenure, Turnover, and Posigovernment Employment Trends of Presidential Appointees". Em: MACKENZIE, G. Calvin, ed. The In-and-Outers. Baltimore: The Johns Hopkins University Press, 1987. p. 187. 
fizeram isso cm empresas cujas atividades tinham relação com seu trabalho no govemo. ${ }^{56}$

Os poucos que aproveitam sua experiência no serviço público $\mathrm{em}$ empregos a cla relacionados no setor privado, parecem fazê-lo como intermediários - lobistas, advogados e consultores. Isso é especialmente verdadeiro com respeito aos advogados nos Estados Unidos, que perfazem $44 \%$ dos ocupantes de cargos em comissão. ${ }^{57} \mathrm{Aposs} \mathrm{um} \mathrm{breve} \mathrm{período}$ no governo, os advogados, especialmente os ex-membros de comissōes regulatórias (metade dos quais passam a trabalhar para as indústrias que fiscalizavam), muitas vezes estabelecem-se em Washington para trabalhar nos mesmos tipos de casos dos quais tratavam quando pertenciam aos quadros do governo. ${ }^{38}$ Esse padrão é adequado para um país como os Estados Unidos, onde boa parte da interação entre govemo c empresas dá-se nos tribunais. De maneira geral, as empresas norteamericanas podem estar dispostas a pagar pelos conhecimentos de alguns ex-burocratas, mas não sentem vontade de fazer deles membros do Conselho de $\mathrm{Admi}$ nistração. ${ }^{39}$

No Brasil, a saida da função pública não segue um padrão claro. Alguns burocratas assumem cargos na alta administração de empresas privadas (tanto nacionais como estrangeiras), embora muitas vezes em setores não relacionados com

\footnotetext{
- $N=984$, STANLEY ct al, op. cit., p. 74. As suas tabulaçōes nāo fornecem um quadro completo da pantouflage nos Estados Unidos. Enquanto $21 \%$ dos 984 servidores retornou aos seus empregos anteriores, 3\% destes "retornaram 2 atividade relacionada com trabalho exccutivo federal", c 5\% "retornaram a atividade não relacionada com trabalho executivo federal". Fica dificil imaginar o que faziam os 13\% restantes.

57. $-\mathrm{N}=1.026$ para o periodo 1930-1\%5. STANLEY ct. al., op. cit., p. 120. Veja também BAUER, op. cit., p. $187-193$ para relatos anedóticos engraçados interessantes sobre emprego pós-funçào pública. Infelizmente, scus dados quantitaivos sào inconclusivos $\mathbf{e}$ incompletos.

38 - QUIRK, op. cit., p.143-144.

39 - O padrào norte-americano lembra mais o amakudarl japonês e francês na indústria de material bélico, embora seja difícil saber a quantidade. Veja CALDER, op. cit., p. 394. O New York Times de 25 de agosto de 1985 estimou que 1.000 pessoas por ano passam através da porta giratória entre o Pentágono e a indústria de material bélico (citado cm KOH, op. cit., p. 250). Em The Poxer Game, op. cit., p. 173, SMITH alega que "em 1983 ... 13.862 oficia is e civis do Pentágono fizcram render os seus contatos dentro do Pentagono ao accitar empregos na indústria de material bélico. De acordo com as curiosas tabulaçōes de STANI.EY et al, op. cit., p. 162, somente uns poucos oficiais que trabalharam em cargos rclacionados com material bélico assumiram empregos relacionados com atividades afins. Para uma boa visão geral de amakudari e de um grupo de consultoria bem conhecido, a Kissinger Associates, veja o New York Times de 30 de abril de 1989, p.1, 30.
} 
sua experiencla no governo; outros tomam-se consultores de intermediação (os lobistas e advogados sāo atores políticos marginais no Brasil); e uma minoria importante ingressa na política. Fntretanto, os padróes de movimen tação tendem a mudar de rumo de acordo com a conjuntura política. Quando o regime militar era especialmente fechado, no início da década de 70 , as empresas privadas contrataram muitos generais e ex-oficiais, mas abandonaram essa prática no final da década. Além disso, o desem. pen ho do ex-oficiais nas eleiçōes era bastante boa quando os militares ditavam as regras c nomearam muitos políticos eleitos. Finalmente, a experiência em algumas óngãos reguladores cria, cedo na carreira, oportunidades de emprego no setor privado, nas indústrias reguladas. ${ }^{60}$

Os burocratas mexicanos aposentam-se, em média aos cinqüenta c sete anos de idade. ${ }^{61}$ Fles não parecem encontrar dificuldade para ocupar uma variedade de postos, principalmente de pouca visibilidade, como professores, consultores, advogados, e na administração de seu próprio patrimônio (eles também nunca ingressam na politica). $O$ estudo mais abrangente realizado até hoje sobre as elites empresariais e do Estado identificou pouco intercâmbio de pessoal. Desde 1935, somente $4 \% \mathrm{~cm}$ média dos servidores públicos de alıo escalāo passaram a ocupar posiçōes importantes na iniciativa privada (embora 15\% dos principais empresários ten ha ocupado cargo público). ${ }^{62}$ Esses valores, relativamente modestos, podem mascarar um papel qualitativamente mais importante de intermediação, na medida em que aqueles políticos que ingressaram na iniciativa privada concentraramse nos bancos, que dominaram a iniciativa privada mexicana $e$ intermediaram as suas relaçóes com o Estado. ${ }^{63}$

De maneira geral, padrōes perenes de amakudari geram três tipos modais de relações entre o empresariado e a burocracia: fusāo, mediaçāo e diferenciação.

60 - SCHNEIDER, op. cit., p. 108-109; DINIZ, Ei, BOSCIU, Renato Raul. Burocra. cia. Clientelismo e Oligopólio. Em: LIMA JR., Olavo Brasil de, ABRANCliES, Sérgio Henrique, eds. As Origens da Crise. Rio de Janeiro, Vértice, 1987, p. 77-78.

61 - SMITH, Peter H. "Does Mexico Have a Power Elite?" Em: REXNA, José Luiz, WEINERT, Richard S., eds. Authoritarianism in Mexico. Philadelphia: Institute for the Study of Ituman Issues, 1977, p.140.

62 - CAMP. Entreprencurs and Politics. Op. cit., p. 79. 82.

63 - Ibid, p. 85 e passim: veja também MAXFIEL.D. Sylvia. Governing Capital. Ithaca: Cornell University Press, 1990. 
Quando muitos burocratas aposentam-se e passam a ocupar altas posiçōes na indústria e na política, o resultado é a fusão da elite industrial, politica e burocrática. À primeira vista, isto pareceria debilitar a autonomia do Estado e da burocracia: esses novos industrais têm uma completa familiaridade com o Estado e acesso privilegiado aos mais altos gabinetes. Mas em casos como os da França e do Japão, que tendem a um padrão de fusão, ocorrem outros fatores que impedem a captura ou a absorçāo do Estado pelos capitalistas. Essa é uma elite cinza, que uma vez que descendeu ao setor privado, não está tão preocupado com a próxima promoçāo e portan to está menos interessada no sucesso da empresa. Além disso, essa é uma elite estatal educada na ética. Na medida em que essa interrelação persiste, poderá fazer mais sentido discutir a captura da indústria pelo Estado. ${ }^{64}$ A ética do samurai e a lealdade aos grands corps provavelmente impedem que exburocratas tornem-se simples utensílios nas mãos dos capitalistas. Eles podem ingressar na política e na iniciativa privada com a autoimagem de uma elite social com a responsabilidade auto-imposta de dirigir a sociedade (no interesse nacional) de qualquer posição que ocupem. Como conclui Johnson no caso japonês de u ma elite que sofreu um processo de fusão, "a distinção ocidental entre público e privado perde seu sentido. ${ }^{63}$

\section{A intermediação e a diferenciação} são mais freqüentes em carreiras pós-serviço público nos Estados Unidos, México e Brasil. Alguns burocratas tornam-se intermediários e vendem o seu conhecimento e familiaridade com as práticas governamentais. $A$ intermedtaçāo estimula a comunicação entre a burocracia e o empresariado e pode suavizar o relacionamento, mas não facilita ou dificulta, necessariamente, o isolamento burocrático. $\Lambda$ continuidade da diferenciaçäo entre elite pública e privada é também um resultado comum nesses três países. Muitos servidores ingressam em cargos e empresas que nada tem a ver com a sua prévia atividade burocrática. A ocorrência de diferenciação é mais provável quando o setor privado não tem como utilizar-se de um conhecimento especifico, como é o caso dos corpos diplomáticos, ou

\footnotetext{
64 - BIRNBAUM, op. cit., p. 64, conclui que o crescente movimento de servidores para a iniciativa privada evidencia "um desejo por parte do Estado de extender seu controle a setores vitais da sociedade."

65 - JOHNSON. MITI and the Japanese Miracic. Op. cit., p. 71 . Veja também KATZENSTEIN, Peier, ed. Between Power and Plenty. Madison: University of Wisconsin Press, 1978, p. 315.
} 
quando o setor privado é menos aberto, como no Brasil e no México, onde ainda predomina o capitalismo familiar. A diferenciação amplia a autonomia burocrática; os servidores preocupam-se menos com o amakudart nos seus últimos anos na função pública c, uma vez aposentados, não oferecem ao cmpresariado nenhum acesso especial ao conhecimento.

Carreiras

- Estruturas de Estado

$\sqrt{1}$

a forma mais simples, a autonomia burocrática será maior se os burocratas de alto escalão forem treinados em um pequeno número de universidades de prestígio (elite de mérito), se seguirem carreiras predominantemente públicas (elite do Estado), se circularem rapidamente por vários órgãos, se forem promovidos através de critérios impessoais de mérito, e se, uma vez aposentados, nāo ingressarem nas empresas privadas que antes supervisionavam. Mas como essas variáveis se somam c se interrelacionam? Seria tentador traçar uma linha no final da Tabela 3 e somar os sim (ou, de forma mais sofisticada, ponderar os fatores e depois somá-los) para se obter um indice da força do Estado.
Infelizmente a aritmética é mais complexa. Em alguns casos, sim $\mathrm{cm}$ duas colunas tem um efeito de sinergia; os valores devem ser elevados ao quadrado ou multiplicados. Em outros casos, um não em uma coluna pode anular um sim em outra.

Em alguns casos, os componentes de carreira diminuem ou anulam uns aos outros. Por exemplo, se o amakudart é universal, ocorre cedo, e é altamente lucrativo c competitivo, então os burocratas deveriam passar a sua carreira no serviço público trabalhando para agradar seu futuros patrões na in iciativa privada. Entretanto, na França e no Japão, onde é mais comum o descenso para o setor privado, o estabelecimento de relações sociais como membro de um grupo com uma ética e uma auto-imagem de clite pública reduz as tentações e confere ao processo uma aura de infiltraçāo do Estado na sociedade. Em outro tipo de interação, uma elite estatal confiante, coerente e de prestigio, pode promover a autonomia, mas se a circulação for baixa e as carreiras amarrarem os servidores às organizaçōes, o conflito e a concorrência interburocráticas restringem a burocracia como um todo. Johnson considera que o conflito interburocrático no Japão é saudável ao colocar rédeas $\mathrm{cm}$ um Estado que de outra forma 
tenderia a excessos burocráticos. ${ }^{66}$ A concorrência entre os grands corps também pode produzir uma tensão ... beneficiente."67

As carreiras também podem diminuir ou aumentar o impacto das variáveis organizacionais sobre preferências $e$ isolamento burocráticos, de manciras que podemos discutir aqui apenas rapidamente. Por exemplo, se as carreiras estāo amarradas a órgãos individuais, a política sobre políticas públicas gira mais $\mathrm{cm}$ torno de metas e conflitos organizacionais. Sc o Estado também é fragmen tado, o conflito no órgão será provavelmente virulento e enfraquecedor, como nos Estados Unidos. A fragmentação excessiva pode imobilizar o aparelho de formulação e implementação de políticas, quando órgãos $\mathrm{cm}$ guerra, com responsabilidades sobrepostas, bloqueiam-se mutuamente. A fragmentaçāo também estimula a estreiteza de opinióes e idéias, o que pode insuflar conflitos paralizantes entre os órgãos e estimular os servidores ligados aos mesmos a se identificarem com os interesses de sua pequena gama de clientes. ${ }^{68}$ Tudo o mais sendo igual, quanto maior a fragmentação, maior a oportunidade para que os atores sociais influenciem as politicas. ${ }^{\natural 9}$ Se uma política industrial passa por muitos órgãos, os empresários podem fazer pressóes em pontos diferentes e provavelmente encontrarão um ponto fraco $\mathrm{cm}$ algum lugar.

A França e o Japão têm poderes legislativos comparativamente fracos c baixos níveis de fragmentação nos scus poderes executivos. Os Estados Unidos são um tipo de arquétipo de fragmentação onde os diferentes poderes foram projetados de modo a serem "capturados por interesses diferentes". ${ }^{70} \mathrm{O}$ Brasil e o México combinam a con-

66 - JOHNSON. MTTI and the Japanese Miracle. Op. cti., p. 78.

67 - ARMSTRONG, op. cit., p. 223. O conflito pode iambém levar a uma paralizaçio completa em ambos os paises. JOHNSON. MITI and the Japanese Miracle. Op. cit., p. 74; ARMSTRONG, op. cit., p. 222.

68 - "Em uma sociedade pluralista, quanto naior o número de unidades $\mathrm{em}$ qua o governo esıá dividido, maior a probabilidade de cada um deles tornar-se ligado aos interesses especiais de sua dientela." ARMSTRONG, op. cin., p. 214. Isto é especialmente verdadeiro se as carreiras dos scrvidores limitam-se àquele único órgào.

69 - NORDLNGER, Op. cit., p. 189.

70 - Nelson Polsby citado em KRASNER, Stephen D. "United States Commerctal and Monetary Policy". Em: KATZENSTEIN, ed., op. cit., p. 61. O artigo de Krasner, bem como outros na cobra de Kazzenstein enfatizam a fragmentaçao e a fraqueza do governo nortea mericano em comparaçào com os Estados de outras democracias industria is. Veja também KRASNER, Stephen D. Defending the National Interests. Princeton: Princeton University Press, 1978. 
TABELA 3

RESUMO DOS PADRŌES DE CARREIRA

\begin{tabular}{|c|c|c|c|c|c|c|}
\hline \multirow[t]{2}{*}{ Especifica̧ào } & \multirow[t]{2}{*}{ Japāo } & \multirow[t]{2}{*}{ França } & \multicolumn{2}{|c|}{ Estados Unldos' } & \multirow[t]{2}{*}{ Brasil } & \multirow[t]{2}{*}{ México } \\
\hline & & & $\begin{array}{l}\text { servblores } \\
\text { públicol }\end{array}$ & $\begin{array}{l}\text { execulivo } \\
\text { políiticos }\end{array}$ & & \\
\hline Elite de Merito & $\operatorname{sim}$ & $\sin$ & nảo & กลืo & não & $\operatorname{sim}$ \\
\hline Elite de Estado & $\operatorname{sim}$ & $\operatorname{sim}$ & $\sin$ & nāo & $\sin$ & $\operatorname{sim}$ \\
\hline Circulaçāo Intensa & nāo & nāo & nāo & กล๊o & $\operatorname{sim}$ & $\sin$ \\
\hline Promoçào p/Mérito & sim & $\sin$ & $\sin$ & náo & nào & nào \\
\hline Pouco amakudart & nâo & não & $\operatorname{sim}$ & nio & sim & $\sin$ \\
\hline
\end{tabular}

servidores públicos de carreira e ocupantes de cargos em comissão.

centraçāo de poder dos poderes executivos do Japão e da França com uma fragmentação como a norte-americana dentro da burocracia. O poder no Brasil e no México está concentrado nas burocracias, mas essas burocracias sāo enormes c estão subdivididas em milhares de órgãos, en tidades au tônomas e empresas estatais. De maneira geral, a baixa circulaçāo $c$ carreiras em um único órgāo enfraquecem a burocracia mediante um maior volume de conflitos entre órgãos e ligações mais estreitas com as clientelas burocráticas. A centralização administrativa, como na França e no Japāo, ou uma circulaçāo mais intensa, como no México e no Brasil, podem frear essas forças centrífugas, que são mais debilitadoras nos Estados Unidos.
Além disso, se a abrangência c a profundidade da intervenção do Estado na economia for grande, e se a maioria dos altos cargos for preenchida por indicação (e sujeita à demissão su mária), cntão - Estado é particularmente vulnerável ao desmantelamento. $\Lambda$ abrangência aguça os interesses, c as indicaçōes fornecem os meios de persegui-los. O uso intenso de nomeações políticas colocou $\mathrm{cm}$ risco a autonomia nos Fistados Unidos (especialmente antes da reforma do serviço público), no México e no Brasil. Entretanto, o efeito é discutivel quando a intervenção do Estado é menor, como nos Estados Unidos. İm contrapartida, os Estados brasileiro e mexicano cram gigantescas instituições fiscalizadoras e de produção: cram proprictários de 
centenas de empresas, canalizavam créditos para investimentos, regulavam a maioria dos fluxos através de fronteiras $\mathrm{e}$ in tervinham na maioria dos setores de forma ampla e específica.

O Estado japonês é muito mais modesto em termos de capacidade produtiva, pessoal, e poder regulatório formal. Por exemplo, o MrTI é uma burocracia muito pequena, com cerca de 300 servidores, o que facilita o controle co isolamento. Scu controle sobre o câmbio c as importações deu-lhe enorme poder sobre o setor privado, o que é usado para persuadir a indústria a alcançar uma grande variedade de objetivos. A França é um caso semelhante, embora menos extremado, de coerência e parcimônia. O Estado francês (especialmente a Comissariat du Plan e o Trésor) controlava fluxos econômicos essenciais, tais como crédito para investimentos. ${ }^{71}$

Quanto mais crescer o papel econômico do Estado, mais provável é que ele internalizará o conflito social e político. ${ }^{72}$ Quan to mais recursos forem alocados pela burocracia, tanto mais os políticos c os grupos de interesse procurarāo influenciar ou capturar importantes partes da mesma, principalmente se os postos de alto escalão tiverem sido preenchidos via nomeação política. As facçōes políticas vitoriosas podem sobrepôr conflitos políticos - que podem estar relacionados ou nāo com as funçōes do órgão - à estrutura administrativa, o que debilita, de dentro, a coerência e a autonomia do Estado.

De maneira geral, os cinco fatores nos cinco casos agrupam-se em síndromes, ou cm duas síndromes e uma exceção. A exceção permanente dos Estados Unidos tem sido analisada extensivamente em outros estudos. ${ }^{73}$ As duas síndromes são mais importantes com respeito a questōes de isolamento burocrático e transformação econômica liderada pelo Estado. Japāo, França, Brasil e México têm tido Estados relativamente autônomos e comparativamente

\footnotetext{
a - Veja ZYSMAN, John. Political Strategies for Industrial Order. Berkeley: University of California Press, 1977, e Governments, Markets and Growth, op. cit.

72 - RUESCHEMEYER e EVANS, op. cit., p. 69, argumentam que "a intervençāo crescente torna o Estado mais claramente um local de disputa de conflitos sociais e torna os seus componentes objetivos mais atraentes de dominaçāo. Em outras pala. vras, as contradiçōes da sociedade civil tornam-se mais arraigadas no Estado, à medida em que o Estado penetra mais profundamente na sociedade civil, debilitando poten. cialmente tanto a sua coerência como ator empresarial como sua autonomia."

73 - Veja especialmente ABERBACH et. al., op. cit., e os estudos comparativos citados na primeira seçio.
} 
eficazes, embora suas burocracias pertençam a duas sindromes diferentes. Na França e no Japão o isolamento burocrático é o resultado de uma sindrome que é estrutural $\mathrm{e}$ institucionalizada; no Brasil e no México é contingente, politizada e em parte nãointencional.

Na França e no Japão a maioria dos fatores opera no sentido de aumentar o isolamento burocrático. O treinamento $\mathrm{e}$ a convivência social são rígidos $e$ as carreiras seguem uma trajetória estatal obrigatória que toma os servidores mais coesos dentro do Estado e mais diferenciados com relação ao resto da sociedade $A s$ promoçōes por mérito livram os servidores de amarras políticas (e o tamanho relativamente pequeno desses Estados toma mais fácil para os servidores rechaçar incursões por parte da sociedade). Somente a circulação mais limitada e o amakudari mais intenso dos servidores japoneses e franceses torna o Estado vulnerável à influência externa, mas a convivência como uma elite do Estado reduz tal risco.

Os Estados brasilciro e mexicano diferem em quase todos os aspectos. Os administradores de elite têm educação, carreiras e convivência social global diferenies. A mobilidade burocrática é menos restrita e menos ligada a objetivos. As nomeações são mais comuns e portanto têm um impacto muito maior sobre o desempenho dos servidores e do Estado. E, para complicar as coisas, o enorme tamanho de ambos os Estados tende a trazer para dentro da burocracia os conflitos sociais e políticos. A maioria desses fatores funciona no sentido de solapar o isolamento. Os servidores têm antecedentes diferentes, e seguem carreiras ad hoc, com prejuizo para a sua coesão e o seu prestígio. Sua dependência da nomeação política pode reprimir os servidores ou destruir o isolamento de seus órgãos: seu isolamento depende basicamente de como os presidentes usam seu poder de nomeação. Somente a rápida e ampla circulação pelo Estado contribui, de forma indireta, para o isolamento. De maneira geral esses Estados são estruturalmente fracos, e faz-se necessário um esforço político constante para dar suporte ao isolamento burocrático.

Além da Autonomia Burocrática 
burocrática. O objetivo era demonstrar a variação sistemática entre paises, que cria diferentes estruturas de incentivo para os scrvidores públicos. Uma análise completa da relação en tre o Estado e a burguesia também exigiria um estudo da ongan ização c orientação dos capitalistas, do papel dos politicos, e das instituições c organização do Estado. Sozinha, a análise das carreiras bu rocráticas não pode mostrar o quadro todo, mas tcorias mais abrangentes ficarão, quando muito, incompletas sem ela.

O teste do argumen to completo que os padróes de carreira moldam o isolamento burocrático c com isso influenciam o desenvolvimento cconômico - exige um tipo diferente de estudo que identificaria preferências específicas $\mathrm{em}$ árcas específicas de políticas, padrões de carrcira não organizados, e buscaria fatores como restriçōes financeiras, articulação no setor privado, politicos e estruturas do Estado. ${ }^{74}$ Nesse tipo de pesquisa empírica, ć provável que os padrōes de carreira surjam como uma das muitas variáveis independentes importantes; entretanto,ainda assim eles deverāo ser capazes de ajudar a justificar a maior parte da variação entre países.
A observação das carreiras burocráticas e sua dependência variável com respeito ao setor privado fornece uma maneira promissora de avaliar a armadura do Estado c para localizar os scus pontos fracos. A análise das carreiras também ajuda a mostrar quando é que conceitos como autonomia estatal e bu rocrática são aplicáveis, a apontar onde são necessários conceitos diferentes ou auxiliares, e a identificar as diferentes bases de isolamento nos Estados que foram relativamente bem-sucedidos na promoção de mudanças na indústria.

Por exemplo, antes de analisar a autonomia do Estado, é preciso saber distinguir entre Estado e sociedade, entre público e privado. $\mathrm{O}$ rastreamento de carreiras levou a duas situaçōes em que a distinção deixou de existir. Na síndrome estrutural, o descenso dos servidores públicos para a administração privada produz. uma elite cinza que parece pairar acima dos limites identificáveis, tanto do Estado como da sociedade. Na síndrome contingente, a distinção também se perde quando as nomeaçōes permitem que o conflito social penctre no Estado. Nesses casos, o emprego de outros conceitos com respeito à política das elites e da burocracia (tais como análise

74 - Como em SCHNELDER, op. cit. 
de classes, de grupos, ou de redes) dá melhores resultados do que usar processos analíticos poderosos para retirar a sociedade de dentro do Estado e vice-versa.

Os conceitos de autonomia do Estado e da burocracia também confundem a análise quando o que realmente está em discussão é a autonomia temporária do governo. A questão é de estruturas versus política. Quando a autonomia governamental c burocrática são institucionalizadas, entāo faz sentido discutir a força do Estado, como na síndrome estrutural. Entretanto, quando a autonomia burocrática é contingente $e$ a força do governo é variável, o uso do conceito de autonomia estatal pode ser enganoso. A questão é ter a capacidade de especificar quando os formuladores de políticas terāo autonomia para formular e implementar políticas que promovam mudanças no setor industrial. $\Lambda$ análise de carreiras pode mostrar se as bases dessa autonomia são estrutura is ou políticas.

Seria tentador voltar ao argumento que inspirou esta pesquisa - que a autonomia burocrática contribui para a intervenção eficaz por parte do Estado - e especificar ainda que a intervenção tem uma probabilidade ainda maior de sucesso quando a autonomia é estrutural e não política. Esse argumento é plausível, e seria provavelmente corroborado por uma comparação en tre os países da Ásia Oriental e da América Iatina que sofreram industrialização rápida. ${ }^{75}$ Entretanto, uma conclusão tão elegante é mais dificil de ser formulada a partir da minha comparação de países que tiveram desenvolvimento precoce e tardio, onde ocorre a influência de muitos outros fatores.

Apesar disso, a comparação sugere a necessidade de revisar o argumento simples de que uma maior autonomia leva a uma intervenção mais eficaz. Mesmo Fistados comparativamente eficazes como o francês e o japonês revelam momentos ou facetas de fraqueza ou permeabilidade. A autonomia burocrática por si pode não ser suficiente sem um clima geral de colaboração e comunicação entre o empresariado e a burocracia. Os Estados eficazes têm

75 - Veja EVANS, "Predatory, Developmental and Other Apparaluses", op. cil.; HAGGARD, Stephan. Pathways from the Periphery. Ithaca: Cornell University Press, 1990; e KIM, Byung-Kook. Bringing and Managing Socioeconomic Change: The State in Korea and Mexico. Dissertaçäo de Doutorado, Universidade de Harvard, 1987. 
uma combinação de isolamento e colaboraçāo, o que Evans chama de autonomia encravada. ${ }^{76}$ Nos casos considerados aqui, os padrōes de carreira ligando os setores público e privado, tais como padrões de amakudari, às vezes facilitaram essa combinação e impediram a ocorrência de extremos de autonomia e de permeabilidade.

\section{Resumen}

\section{LA CONEXION DE LA CARRERA}

um analisis de preferencias y aislamien to burocraticos, el trabajo pone en relieve la relación entre los futuros servidores gubernamentales con el sector privado, haciendo hincapié en las interacciones establecidas, por um lado de las perspectivas funcionales en las carreras del sector público y, por otro, las influencias del poder economico ejercidas por los empresarios.

Así, son presentados datos sobre las experiencias norteamericana, francesa, japonesa, mexicana y brasileira.

\section{Absiract}

THE CAREER CONNECTION: A COMPARATIVE ANALYSIS OF BUREAUCRATIC PREFERENCES AND INSULATION

The paper enphasisis the relation of future governmental servants with the private sector, focousing on the constructed interfaces, on one hand, of the functional perspectives of the public sector career, and, on the other, by the influences of the economic power exercised by the private sector. In this sense, data on the North American, French, Japanese, Mexican and Brazilian experiences are presented.

76 - EVANS, "Predatory, Developmental and Other Apparatuses", op. cit. 
Título original: The Career Connection: a comparative analysis of bureaucratic preferences and insulation.Publicado em abril de 1993 na Revista Comparative Politics, pp. 331-350.

Traduzido com autorização dos editores.

Ben Ross Schneider é professor de Ciência Política da Northwestern University 